\title{
Some Charophyta (Charales) from Coastal Temporary Ponds in Velipoja Area (North Albania)
}

\author{
Vilza Zeneli ${ }^{1}$ and Lefter Kashta ${ }^{2}$ \\ 1. Department of Biology, Faculty of Natural Sciences, The University of Tirana, Tirana 1001, Albania \\ 2. Research Center of Flora and Fauna, Faculty of Natural Sciences, The University of Tirana, Tirana 1001, Albania
}

\begin{abstract}
Charophytes or stoneworts constitute a group of macrophytes that occur mostly in fresh-water environments but can also be found in brackish waters. Knowledge about stoneworts in Albania is still scarce and incomplete. According to published data on charoflora of Albania, there are 24 species and four genera known from different freshwater habitats. The present work is based on plant material sampled from 5 slightly brackish-water temporary ponds in the coastal area of Velipoja (north Albania). During spring and summer of 2013-2015, field surveys were carried out with the main purpose of filling knowledge gaps concerning brackish water charophytes. Altogether seven species were identified: four typical of brackish water habitat (Chara baltica, Chara canescens, Chara galioides and Chara connivens) and three of broader tolerance (Chara aspera, Chara vulgaris and Tolypella glomerata). The first three species, which considered as the rarest and most threatened on the Balkans were found for the first time in Albania.
\end{abstract}

Key words: Charophyta, brackish water, Albania, Velipoja area, temporary ponds.

\section{Introduction}

Charophytes or stoneworts are a group of macroscopic green algae that occur worldwide. They are mostly inhabitants of fresh water, but about a dozen of species can be found in brackish water where they are able to withstand large salinity fluctuations [1-4]. Some of them are halo-tolerant species, meaning taxa that usually occur in freshwater but are able to support low amounts of salt and some others are true halophilous species, meaning they need salinity to germinate and grow [1]. Chara canescens, Chara baltica and Chara galioides are known as true halophilous [5].

The Balkan Peninsula is distinguished by a rich charophyte flora, which is still insufficiently well known and its entire richness has not yet been recognized [6]. Knowledge about stoneworts in Albania is still scarce and incomplete. According to published data, 24 species, divided between genera Chara (15 species), Nitella (7 species), Nitellopsis

Corresponding author: Vilza Zeneli, master, research field: conservation biology/plants direction. (one species) and Tolypella (one species) were reported for Albania from different freshwater habitats like lakes, rivers, ponds, etc. [7-9].

Field surveys were carried out last years with the main purpose of filling knowledge gaps concerning brackish water charophytes. In the present work, it is reported the occurrence of some charophyte species in brackish temporary ponds from Velipoja area.

\section{Material and Methods}

The Buna/Bojana delta, situated on the Albanian-Montenegrin border, is characterised by different brackish and fresh water habitats favorable for the development of high flora and fauna diversity. It is the most important wetland system along the Adriatic sea and one of the best preserved in the Mediterranean [10]. Velipoja area is located in Albanian part of this delta (Fig. 1).

The material was collected during spring and summer 2013-2015 in five localities, which represent small temporary ponds with slightly brackish water, located in sand dunes system (Fig. 1). These ponds remain flooded during winter and spring, namely a 


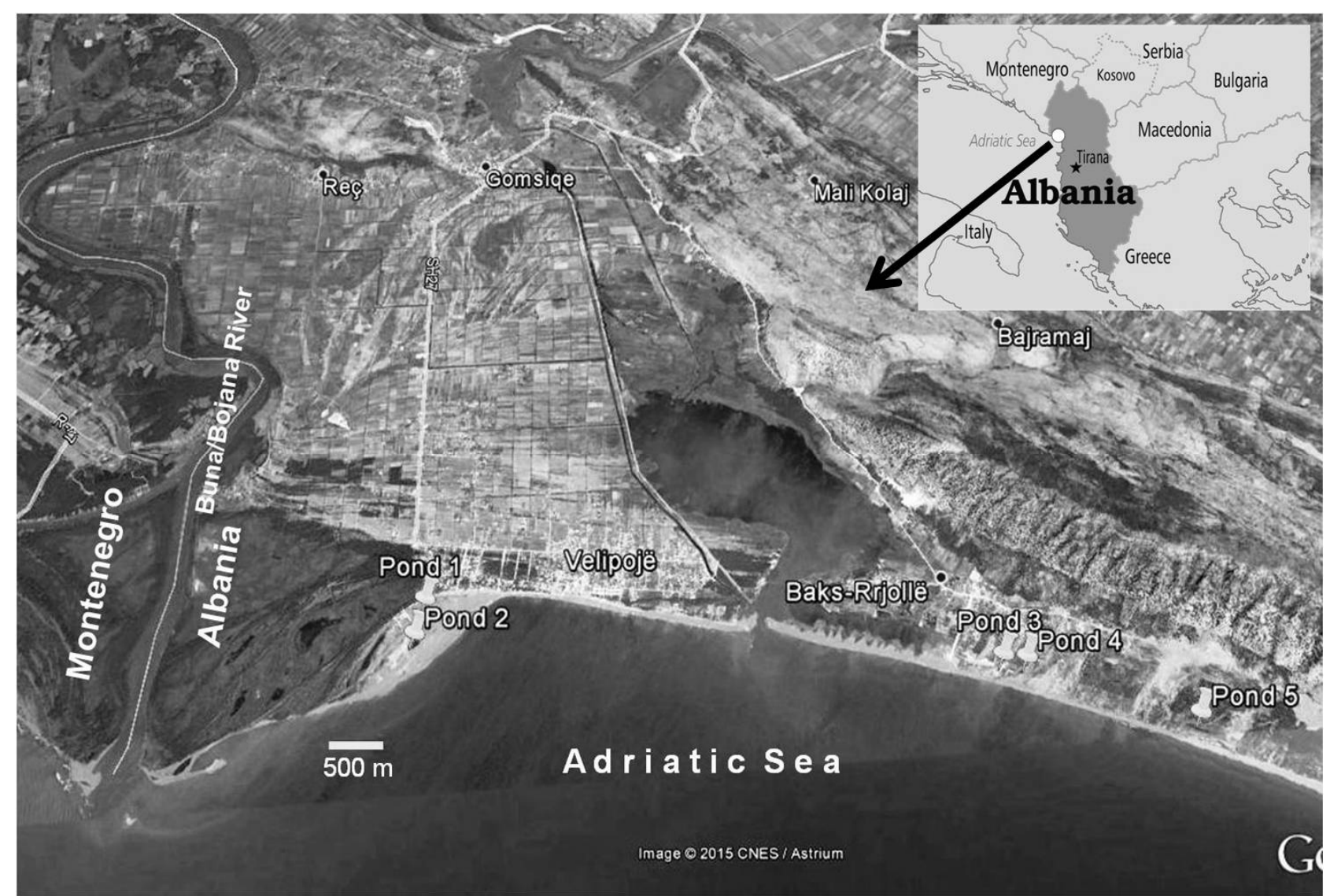

Fig. 1 The map of sampling localities-brackish temporary ponds in Velipoja area, the specimens were determined using different keys and nomenclature of the stoneworts follows Krause, W. [4, 15-17].

period sufficient to complete life cycle of the Characeae, from seed to fructification and production of oospores [11]. This type of habitat undergoes fluctuations in salinity as it is subject to infiltration of seawater, inundation during storms and rainfall. Considered as slightly brackish waters of young developing dune slacks, according to Habitats code-EUR27, it can be included in Humid depressions of sand dune system (code 2190) [12-14].

The material collected has been preserved and kept in the collection of National Herbarium, Faculty of Natural Sciences at University of Tirana.

Some physical/chemical data of sampling localities are given in Table 1. Salinity and $\mathrm{pH}$ of the water in ponds 1 and 2 are measured at the end of April 2015.

The sampling localities with charophytes (Fig. 2) are briefly commented:

Locality 1 : very shallow pond $(0-20 \mathrm{~cm})$ with clear, slightly brackish and alkaline water $(\mathrm{S}=0.8 \%$ and $\mathrm{pH}$ = 7.4) which become dry at the end of May or first week of June, generally with bare sandy-silt substrate, rarely with few Bolboschoenus maritimus or Stuckenia pectinata. In addition, drained channels bordered by Juncus sp. and Tamarix gallica are parts of this locality;

Locality 2: shallow pond $(0-50 \mathrm{~cm})$, with clear, slightly brackish and alkaline water $(\mathrm{S}=1.6 \%$ and $\mathrm{pH}$ $=8.1$ ), which become dry at the end of July or first week of August, partly bare sand substrate and stands of Bolboschoenus maritimus; by June with dense stands of Stuckenia pectinata;

Locality 3: periodically inundated sandy dune depression, like a salt marsh, with moderately clear water, which became dry at the end of May. Sandy and sandy-silt substrate with large stands of Juncus acutus were sparsely grows also Ruppia cirhosa; 
Table 1 Characteristics of sampling localities and charophyte species found.

\begin{tabular}{|c|c|c|c|c|c|c|c|}
\hline Locality & $\begin{array}{l}\text { Depth } \\
(\mathrm{m})\end{array}$ & Substrate & $\begin{array}{l}\text { Salinity } \\
(\%)\end{array}$ & $\mathrm{pH}$ & Charophytes & Other macrophytes & Became dry \\
\hline 1 & $0-0.2$ & Sandy-silt & 0.8 & 7.4 & $\begin{array}{l}\text { Chara aspera, } \\
\text { Chara baltica, } \\
\text { Chara canescens, Chara } \\
\text { connivens, } \\
\text { Chara galioides, } \\
\text { Chara vulgaris, } \\
\text { Tolypella glomerata }\end{array}$ & $\begin{array}{l}\text { Bolboschoenus } \\
\text { maritimus, } \\
\text { Stuckenia pectinata }\end{array}$ & end of May \\
\hline 2 & $0-0.5$ & $\begin{array}{l}\text { Sandy, } \\
\text { Sandy-silt }\end{array}$ & 1.6 & 8.1 & $\begin{array}{l}\text { Chara baltica } \\
\text { Chara aspera }\end{array}$ & $\begin{array}{l}\text { Bolboschoenus } \\
\text { maritimus, } \\
\text { Stuckenia pectinata }\end{array}$ & end of July \\
\hline 3 & $0-0.2$ & Sandy mud & - & - & Chara canescens & Ruppia cirhosa & end of May \\
\hline 4 & $0-0.6$ & $\begin{array}{l}\text { Sandy, } \\
\text { Sandy-silt }\end{array}$ & - & - & Chara canescens & $\begin{array}{l}\text { Ruppia cirhosa, } \\
\text { Stuckenia pectinata, } \\
\text { Scirpus sp. }\end{array}$ & $\begin{array}{l}\text { end of July } \\
\text {-August }\end{array}$ \\
\hline 5 & $0-0.3$ & Sandy mud & - & - & Chara canescens & Ruppia cirhosa & end of May \\
\hline
\end{tabular}

Locality 4: relatively large shallow pond is surrounded by stands of Juncus acutus, except the part toward the sea. On the upper part toward the land, where few freshwater enter the pond, Scirpus sp. grow in large stands;

Locality 5: periodically inundated sandy dune depression, like a salt marsh, which became dry at the end of May, surrounded by stands of Juncus acutus, sandy mud substrate with stands of Ruppia cirhosa.

\section{Results and Discussion}

Seven species of stoneworts were found and identified, representing the genera Chara and Tolypella: Chara baltica, Chara canescens, Chara galioides, Chara aspera, Chara connivens, Chara vulgaris and Tolypella glomerata. The most common species is Chara canescens which was recorded almost at all localities followed by Chara aspera and Chara baltica.

3.1 Chara baltica Bruz. 1824 (Syn.: Chara hispida var. baltica (Bruz.) R.D. Wood 1962)

Chara baltica (Fig. 3) recorded here as new to Albania, was found in shallow ponds (localities 1 and 2) with clear, slightly brackish and alkaline water, in sandy or sandy-silt substrate, forming monospecific population or associated with Chara aspera, Chara canescens, Chara galioides and Chara connivens. The first individuals have been observed since the end of March. Ripe oospores were found in June and July.

Description: the plants are fresh green, $10-25 \mathrm{~cm}$ long, with axis to $1 \mathrm{~mm}$ in diameter, without or only slightly encrusted. The cortex is regularly 2-corticated, rarely 3-corticated, normally tylacanthous. Spine cells solitary, occasionally in pairs, are shorter or longer than axis diameter, acuminate. Stipulodes are in two rows well developed, similar to spine cells, branchlets 8-9 in a whorl with 2-5 corticated and 1-2 ecorticated segments. The sheltered plants among Stuckenia pectinata, with 1-2 outermost segments elongate are inflated and transparent. The bract-cells are variable in length, the posteriors are shorter than anterior. Mature oogonia is $800-900 \mu \mathrm{m}$ long (without coronula) and 500-600 $\mu \mathrm{m}$ wide. The coronula is large, $180-230 \mu \mathrm{m}$ high and 330-360 $\mu \mathrm{m}$ wide. Oospores are black, with 11-12 striae, antheridia orange-red, large, 500-550 $\mu \mathrm{m}$.

The clear identification of the species is problematic, because no single morphologic character was found that can separate Chara baltica and Chara intermedia $[18,19]$. They are usually separated from each other by habitat salinity [20]. The findings in Velipoja area, in similar habitats with Chara canescens, Chara aspera, Chara galioides and Tolypella glomerata are in accordance with the literature data about the distribution in Mediterranean coast [4, 21, 22]. 

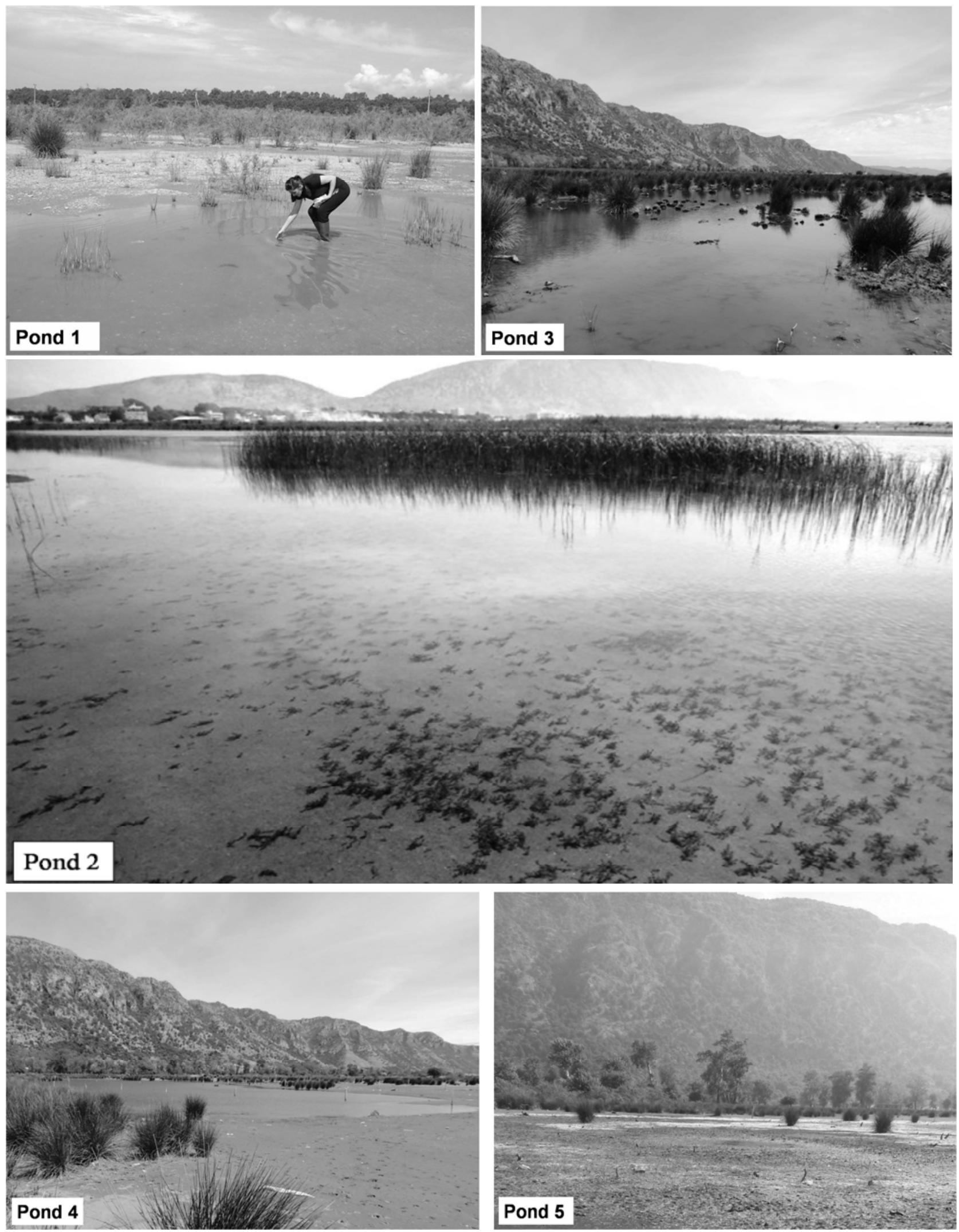

Fig. 2 View of five sampling localities (ponds) in Velipoja area, Chara baltica can be seen in the foreground of the pond 2. 

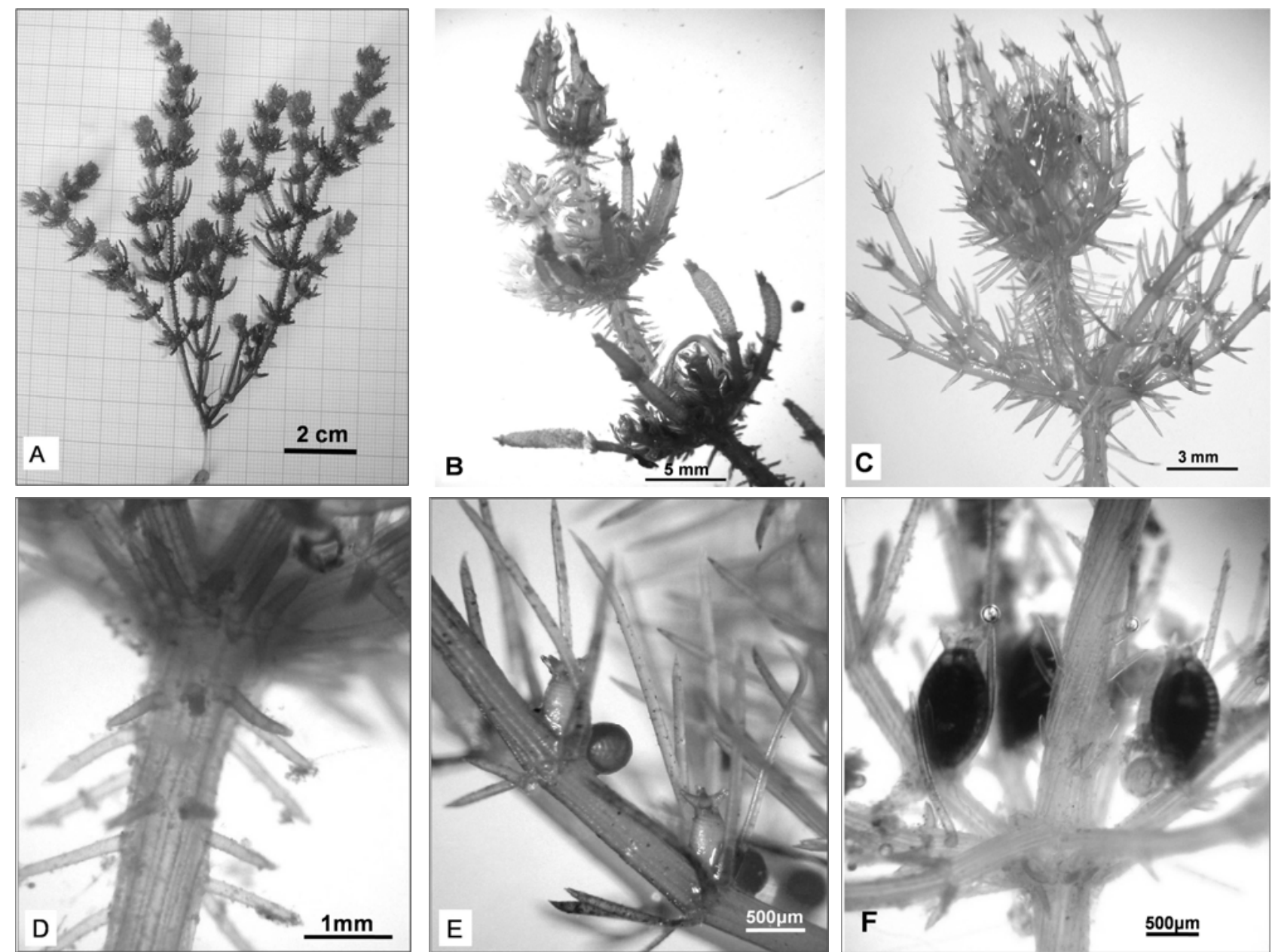

Fig. 3 Chara baltica: (A) the habit of a small plant found between stands of Stuckenia pectinata, (B) the upper part of this plant with short spine cells and some swollen segments, (C) upper whorls of a plant with long spine cells, (D) view of steam with diplostichous (and partially triplostichous) tylacanthous cortification, (E) fertile branch with unripe oogonia and antheridia and (F) mature oogonia with large divergent coronula.

The finding of Chara baltica in Velipoja area is of special importance, since populations of this species are globally restricted to the Baltic sea [21]. The species has been found also in Britain, Poland, Portugal and Mediterranean coast in Spain, France, Morocco, Algeria, Tunisia and Sardinia, Italy [4, 23, 24]. In Adriatic coast, it is recorded in the brackish lake Fiesa in Slovenia [6, 25].

\subsection{Chara canescens Desv. et Lois. 1810 (Syn.: Chara} crinita Wallr. 1815)

Chara canescens (Fig. 4) recorded here as new to Albania was found to grow in all surveyed localities, but in localities 1 and 5 was more abundant. The species represents populations with only female plants, like in the northern parts of Europe and Mediterranean coast [19, 26, 27]. In the area, it covers ponds bottom at a depth of 0.1-0.2 $\mathrm{m}$, forming a monospecific population or associated with Chara baltica and Chara aspera or Tolypella glomerata. Its presence was recorded from middle April to late July.

Chara canescens is common in the northern hemisphere and its occurrence is restricted to brackish waters [3, 4, 21, 27, 28]. In Europe, it is found scattered along the coasts and in south east of the continent, many localities have been lost [4, 28]. In the Balkans, the species occurs in Bosnia and Herzegovina, Bulgaria, Romania, Greece and Serbia $[6,29]$. 


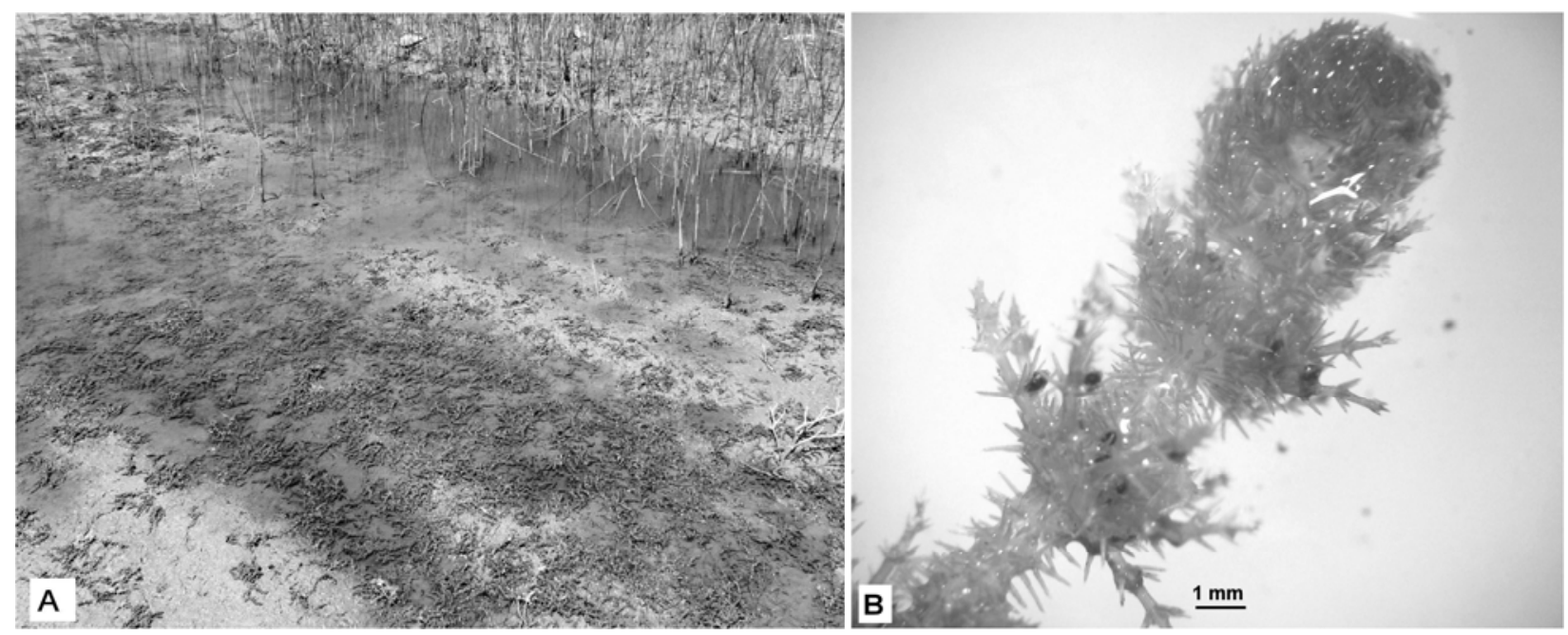

Fig. 4 Chara canescens: (A) stands of the plant in site 1 and (B) upper whorls with oogonia.
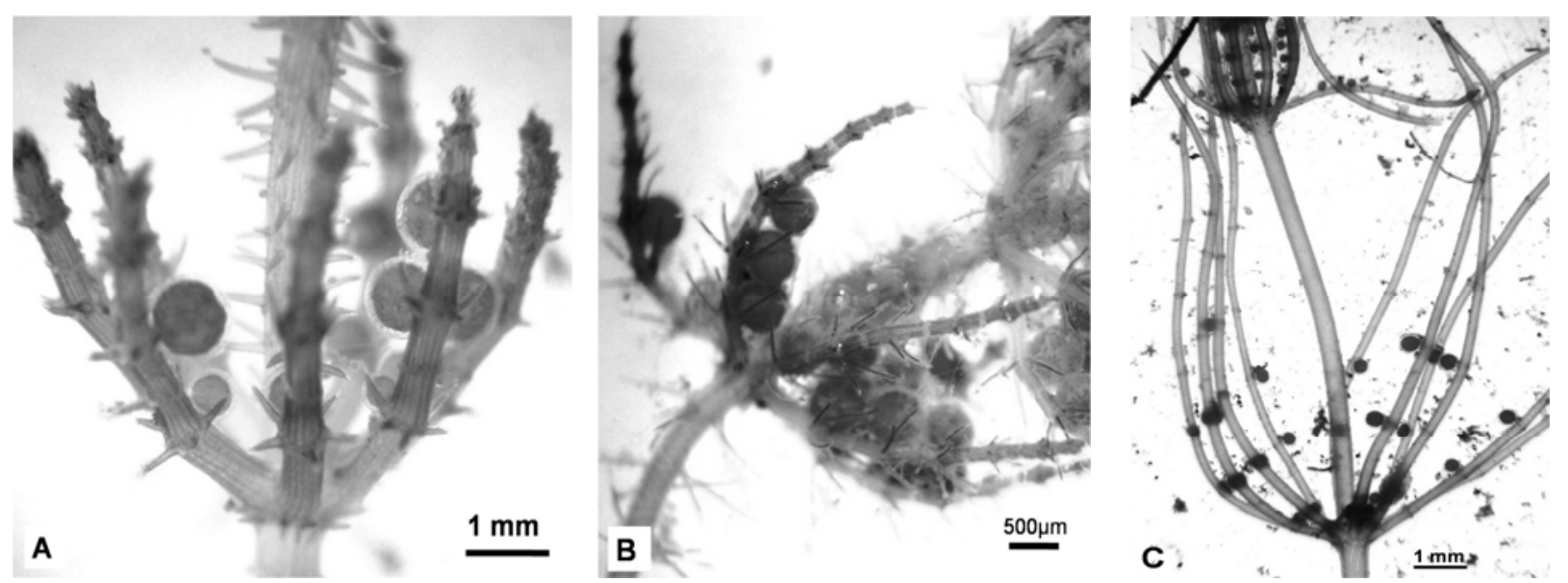

Fig. 5 (A) Chara galioides, male plant, (B) Chara aspera, male plant and (C) Chara connivens, male plant.

3.3 Chara galioides DC. 1813 (Syn.: Chara aspera var. galioides (DC.) Hartm., Chara globularis var. aspera f. galioides (DC.) R.D. Wood)

Chara galioides (Fig. 5a) recorded here as new to Albania was sampled sparsely in spring, only in a shallow canal close to the pond 1 . Only male plants were found. Most of specimens had antheridia greater than 800 microns. Chara galioides and Chara aspera are closely related species that can be differentiated by the size of their antheridia, the dimensions of the spine cells, the diameter of the main axis and the length of the anterior and posterior cells [30].

The species occurs throughout Europe, from Scandinavia to the Mediterranean and northern Africa and it is found exclusively in brackish water $[4,15,30]$.
In the south of France, it grows with Chara baltica, Tolypella nidifica, Tolypella hispanica, Tolypella glomerata or with Lamprothamnium papulosum or Chara canescens [4]. In the Balkans, it is recorded only in Greece, recently including Crete [6,31].

3.4 Chara aspera Dethard. ex Willd. 1809 (Syn.: Chara globularis var. aspera (Dethard. ex Willd.) R.D. Wood)

Chara aspera (Fig. 5b) was observed several times in spring and early summer in two localities (ponds 1 and 2), growing scattered in a mixed vegetation together with Chara baltica and Chara canescens. In Albania, it has been reported previously from Shkodra and Vlora coastal area and from lake Ohrid [8, 32]. 

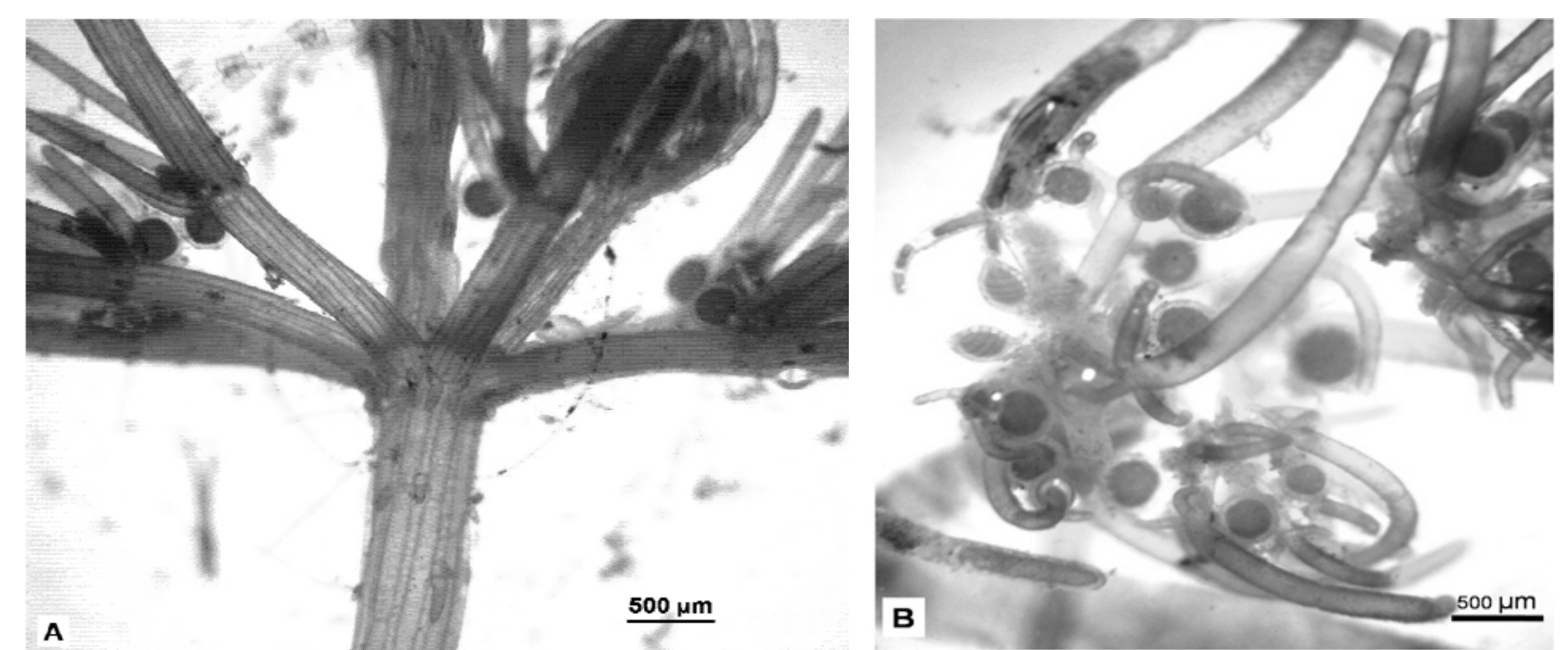

Fig. 6 (A) Chara vulgaris var. vulgaris with fertile whorls and (B) Tolypella glomerata with antheridia and oogonia, Tolypella glomerata (Desv.) Leonh. 1863 (Syn.: Tolypella nidifica var. glomerata (Desv. In Lois) R.D. Wood 1962).

Chara aspera occur in both brackish and freshwater. It is a very common species in Europe, Africa, Asia and north America [30]. In the Baltic sea region, the species was found to grow scattered in a mixed vegetation together with Chara baltica Bruz., Chara canescens, etc. [33].

3.5 Chara connivens Salzm. ex A. Br. 1835 (Syn.: Chara globularis f. connivens (Salzm. ex A. Br.) R.D. Wood 1962)

Chara connivens (Fig. 5c) previously recorded close to Buna/Bojana river mouth was found sparsely in locality 1 only [32]. The species is dioecious, both fertile male and female plants are sampled during the spring 2015.

This species can occur in brackish or in a calcareous fresh water [17]. Chara connivens is a very rare species in the Mediterranean region, and it is reported as rare in European level [4, 11]. In the Balkans, it is found in Bulgaria, Croatia, Greece, Montenegro, Romania and Serbia [6, 29].

3.6 Chara vulgaris var. vulgaris L. 1753 (Syn.: Chara foetida A. Braun 1834)

Chara vulgaris (Fig. 6a) was sampled rarely in springtime in locality 1 only, growing together with Tolypella glomerata. This halotolerant freshwater species is an inhabitant of oligohaline environments [3]. Chara vulgaris is a common species in Albania, but this is the first finding in brackish waters. Chara aspera and Chara vulgaris are recorded in all Balkan countries [6].

Tolypella glomerata (Fig. 6b) was found richly fertile in early spring in the locality 1 only. In late April, it disappears and replaced by Chara canescens.

Tolypella species are commonly found in brackish environments [3]. Tolypella glomerata shows wide ecological amplitude and can be found in aquatic ecosystems from fresh to saline waters, especially in ephemeral vernal pools developed there during early spring [34, 35]. The species is fairly common throughout Europe, while in the Balkans, it is rare and redlisted as Endangered species (EN) $[6,36]$. In Albania, it was previously recorded in a freshwater marsh near Velipoja [32].

\section{Conclusions}

Altogether seven species were identified in study area: four typical of brackish water (Chara baltica, Chara canescens, Chara galioides and Chara connivens) and three of broader tolerance (Chara aspera, Chara vulgaris and Tolypella glomerata).

The first three species were found for the first time in Albania. This is also the first report of Chara 
vulgaris and Tolypella glomerata in brackish water.

According to Blaženčić, J. et al. [6], five of the species found in the area are classified as threatened in the Balkans: Chara baltica and Chara galioides as Critically Endangered (CR), Chara connivens and Tolypella glomerata as Endangered (EN) and Chara canescens as Vulnerable (VU).

The first reporting of Chara baltica, Chara galioides and Chara canescens in Velipoja area is significant, not only as new species for charoflora of Albania, but also for the Balkans, considering that these are among the rarest and most threatened species of the region.

The results of the present study demonstrate that the charoflora of Albania is still insufficiently recognized and more attention should be paid on the presence of these interesting algae in the coastal habitats.

\section{References}

[1] Soulié-Märsche, I. 2008. "Charophytes, Indicators for Low Salinity Phases in North African Sebkhet.” Journal of African Earth Sciences 51: 69-76.

[2] Beilby, M. J. 2015. "Salt Tolerance at Single Cell Level in Giant-Celled Characeae." Front Plant Sci. 6: 1-16. doi:10.3389/fpls.2015.00226.

[3] Winter, U., Soulié-Märsche, I., and Kirst, G. O. 1996. "Effects of Salinity on Turgor Pressure and Fertility in Tolypella (Characeae)." Plant Cell and Environment 19: 869-879.

[4] Krause, W. 1997. Krause, W. 1997. Charales (Charophyceae). Jena/Stuttgart/Lübeck/Ulm: Fischer University Press. (in German)

[5] Lambert, E., Desmots, D., Bail, J. L., Mouronval, J. B., and Felzines, J. C. 2013. "Tolypella salina R. Cor. on the French Atlantic Coast: Biology and Ecology." Acta Botanica Gallica: Botany Letters 160 (2): 107-119.

[6] Blaženčić, J., Stevanović, B., Blaženčić, Ž., and Stevanović, V. 2006. "Red Data List of Charophytes in the Balkans." Biodiv. Conserv. 15: 3445-3457.

[7] Hospers, A., and Hospers, M. 2001. "Locations of Characea during JNM Jeugdbond Holiday in Albania." National Herbarium in Leiden. Accessed May 27, 2001. $\mathrm{http} / / /$ natuurreis.scienceontheweb.net/albania/travel\%20d escription\%20benca.htm.

[8] Kashta, L., Perçini, D., and Molla, O. 2013. "Data on the Diversity and Ecology of Charophyte Algae in Lake Ohrid.” Bul. Shk. Nat. 15: 142-150.
[9] Langangen, A. 2015. "Charophytes Collected in the Southern Part of Sarandë District, Albania.” Bul. Shk. Nat. 19: 6-11.

[10] Stumberger, B., Schneider-Jakoby, M., Schwarz, U., Sackl, P., Dhora, D., and Savelic, D. 2005. "The Ornithological Value of the Bojana/Buna Delta." Bul. Shk. Ser. Shk. Nat. 55: 136-158.

[11] Soulié-Märsche, I. 2003. The Characeae of Three Lakes of Centre Var Good Cougne-Redon-Gavoti. Expert report.

[12] Westhoff, V. 1997. "Hygrosere of Dune Slacks on the Westfrisian Islands." In the Ecology and Conservation of European Dunes, 51-58.

[13] Davy, A. J. 2006. Development of Eco-hydrological Guidelines for Dune Habitats: Phase 1. English Nature Research reports.

[14] Felzines, J. C., and Lambert, É. 2012. “Contribution au Prodrome des Végétations de France: Les Charetea Fragilis F. Fukarek 1961.” J. Bot. Soc. Bot. 59: 133-188. (in France)

[15] Cirujano, S., Cambra, J., Sánchez, Castillo, A., Meco, A., and Flor Arnau, N. 2008. Iberian Flora, Continental Algae, Stonworts (Characeae). Madrid, Spain: Royal Botanic Gardens. (in Spanish)

[16] Bazzichelli, G., and Abdelahad, N. 2009. Freshwater Algae of Italy, Analytical Flora of Stoneworts. Rome: University of Rome La Sapienza (in Italian).

[17] Urbaniak, J., and Gabka, M. 2014. Polish Charophytes, an Illustrated Guide to Identification. Wroclaw: Wroclaw University of Life Sciences.

[18] Bögle, M. G., Schneider, S., Mannschreck, B., and Melzer, A. 2007. "Differentiation of Chara intermedia and Chara baltica Compared to Chara hispida based on Morphology and Amplified Fragment Length Polymorphism." Hydrobiologia 586: 155-166.

[19] Barnes, M., and Wilding, C. 2009. "Chara baltica, Baltic Stonewort.” Accessed April 16, 2015. http://www.marlin.ac.uk/speciesfullreview.php?speciesID $=4736$.

[20] Bögle, M. 2012. "Speciation in Charophytes-A Multidimensional Approach." Ph.D. thesis, Technical University of Munich.

[21] Küster, A., Schaible, R., and Schubert, H. 2004. "Light Acclimation of Photosynthesis in Three Charophyte Species.” Aquatic Botany 79: 111-124.

[22] Soulié-Märsche, I., Muller S. D., and Daoud-Bouattour, A. 2011. "New Investigations on Charophytes from North Africa." In The 18th Meeting of the Group of European Charophytologists (GEC), 15-18.

[23] Guiry, M. D., and Guiry, G. M. 2015. "Algae Base." Accessed May 3, 2015. http://www.algaebase.org.

[24] Weyer, K. 2015. “Chara baltica Bruzelius (Characeae) 
Recorded in Sardinia." In International Symposium on Mediterranean Temporary Ponds, 28.

[25] Firbas, P., and Al-Sabati, K. 1995. "Cytosystematic Studies on the Charophyta in Slovenia." Arch. Biol. Sci. 47 (1-2): 49-58.

[26] Schaible, R., and Schubert, H. 2008. "The Occurrence of Sexual Chara canescens Populations (Charophyceae) is not Related to Ecophysiological Potentials with Respect to Salinity and Irradiance." Eur. J. Phycol. 43 (3): 309-316.

[27] Schaible, R., Bergmann, I., and Schubert, H. 2011. "Genetic Structure of Sympatric Sexually and Parthenogenetically Reproducing Population of Chara canescens (Charophyta)." International Scholarly Research Network 501838: 13. doi:10.5402/2011/501838.

[28] Langangen, A. 2014. "Charophytes (Charales) from Samos and Ikaria (Greece) Collected in 2013 and Report on Some Localities in Skiathos (Greece)." Fl. Medit. 24: 139-151.

[29] Blaženčić, J. 2014. "Overview of the Stoneworts (Charales) of Serbia with the Estimation of the Threat Status." Botanica Serbica 38 (1): 121-130.

[30] Flor-Arnau, N., Reverter, Soulié-Märsche, F., and
Cambra, J. 2006. "Morphological Differentiation of Chara aspera Detharding Ex and Chara gallioides De Candolle under Different Environmental Variables." Cryptogamie, Algol. 27 (4): 435-449.

[31] Bergmeier, E., and Abrahamczyk, S. 2008. "Current and Historical Diversity and New Records of Wetland Plants in Crete, Greece." Willdenowia 38: 433-453.

[32] Kashta, L. 2009: "Charophyte Flora of Shkodra Region." Bul. Shk. Ser. Shk. Nat. 59: 97-106.

[33] Blindow, I., Dietrich, J., Möllmann, N., and Schubert, H. 2003. "Growth, Photosynthesis and Fertility of Chara aspera under Different Light and Salinity Conditions." Aquatic Botany 76: 213-234.

[34] Cirujano, S., Guerrero Maldonado, N., and García Murillo, P. 2013. "The Genus Tolypella (A. Braun) A. Braun in the Iberian Peninsula." Acta Botanica Gallica 160 (2): 121-129.

[35] Grillas, P. 1990. "Distribution of Submerged Macrophytes in the Camargue in Relation to Environmental Factors.” J. Veg. Sci. 1: 393-402.

[36] Moore, J. A. 1986. Charophytes of Great Britain and Ireland. London: BSBI Handbook. 